\title{
The Alvarrões-Gonçalo Li project: an example of sustainable lithium mining
}

\author{
Rui Sousa ${ }^{1}$, Violeta Ramos ${ }^{2}$, Alexandra Guedes ${ }^{2,3}$, Fernando Noronha ${ }^{2}$, Ana Botelho de Sousa ${ }^{1}$, \\ Mário Machado Leite ${ }^{1}$, Reimar Seltmann ${ }^{4}$, and Alla Dolgopolova ${ }^{4}$ \\ ${ }^{1}$ Laboratório Nacional de Energia e Geologia, Rua da Amieira, Apartado 1089, S. Mamede de Infesta, Portugal \\ ${ }^{2}$ Institute of Earth Sciences, Pole Porto, University of Porto, Rua do Campo Alegre, 4169-007 Porto, Portugal \\ ${ }^{3}$ Department of Geosciences, Environment and Spatial Planning, Faculty of Sciences, University of Porto, \\ Rua do Campo Alegre, 4169-007 Porto, Portugal \\ ${ }^{4}$ Natural History Museum, Department of Earth Sciences, CERCAMS, Cromwell Road, London SW7 5BD, UK
}

Correspondence: Violeta Ramos (violetaramos@fc.up.pt)

Received: 30 May 2018 - Accepted: 2 July 2018 - Published: 16 July 2018

\begin{abstract}
Across Europe, small scale deposits of critical materials and/or strategic elements, such as $\mathrm{W}, \mathrm{Li}$ and $\mathrm{Sn}$, are not viable to mine and process using the traditional large scale mining and processing technologies due to their geological characteristics. Project FAME (Flexible And Mobile Economic Processing Technologies, EC Horizon 2020 Grant Agreement No. 641650) was created in order to specifically address the technical and environmental challenges to the sustainable processing of low sulphide ores from pegmatites, greisens and skarns deposits. One of the deposits, Alvarrões-Gonçalo, is a Li pegmatite located at the Gonçalo pegmatite field (Central Portugal) that is being investigated on the scope of the concerned project. Currently, the pegmatites are only being exploited for ceramics, aggregates and ornamental purposes, however, there is exploitation potential for $\mathrm{Li}_{2} \mathrm{O}$-rich ores. Froth flotation is being tested to produce a lepidolite concentrate. Results showed the feasi-

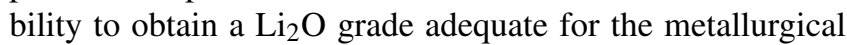
production of lithium compounds as $\mathrm{Li}_{2} \mathrm{CO}_{3}$. The lepidolite flotation rejects, normally stored in tailings dumps, are mainly composed by a mixture of feldspars, quartz and nonrecovered lepidolite (though a very low content), which is, by itself, a very interesting raw material for ceramic purposes. Consequently, mining exploitation of lepidolite, as $\mathrm{Li}_{2} \mathrm{O}$ ore, from pegmatite could comply with the standards of "green mining", reaching an almost "zero waste" exploitation, as it can be accomplished in the case of the mineral processing of the Alvarrões-Gonçalo lithium ore. This basic scenario could be improved by applying froth flotation also
\end{abstract}

for feldspars/quartz separation, aiming at obtaining a high content feldspars concentrate (floated) and a quartz product (non-floated): the feldspars concentrate can be used to produce blends with different ratios feldspars/quartz for sanitary ware and tiles and quartz for other uses, such as glasses and "silica flour".

\section{Introduction}

The word sustainable is increasingly connected to several industries throughout the world. In 1987, the Bruntland Commission clearly defined the word sustainable as the compromise of present generations to ensure that future generations can meet their own life-sustaining needs (United Nations, 1987). The development of new waste management strategies could be an encouraging way to ensure future generations sustainability. This idea conducted to the formulation of the "zero waste" concept, proposed by the Zero Waste International Alliance in 2014, having as main goal to promote practices that enhance the creation of sustainable natural cycles, in which wasting material must be converted in a resource for others to use, i.e. to develop products and processes that avoid the volume of waste materials (Sauer and Seuring, 2017; Sverdrup and Ragnarsdottir, 2014; ZWIA, 2015; Arndt et al., 2017; Burlakovs et al., 2018).

In general terms, "Green Mining" can be described as the implementation of technologies and mining processes targeting at reducing any possible environmental footprints asso- 


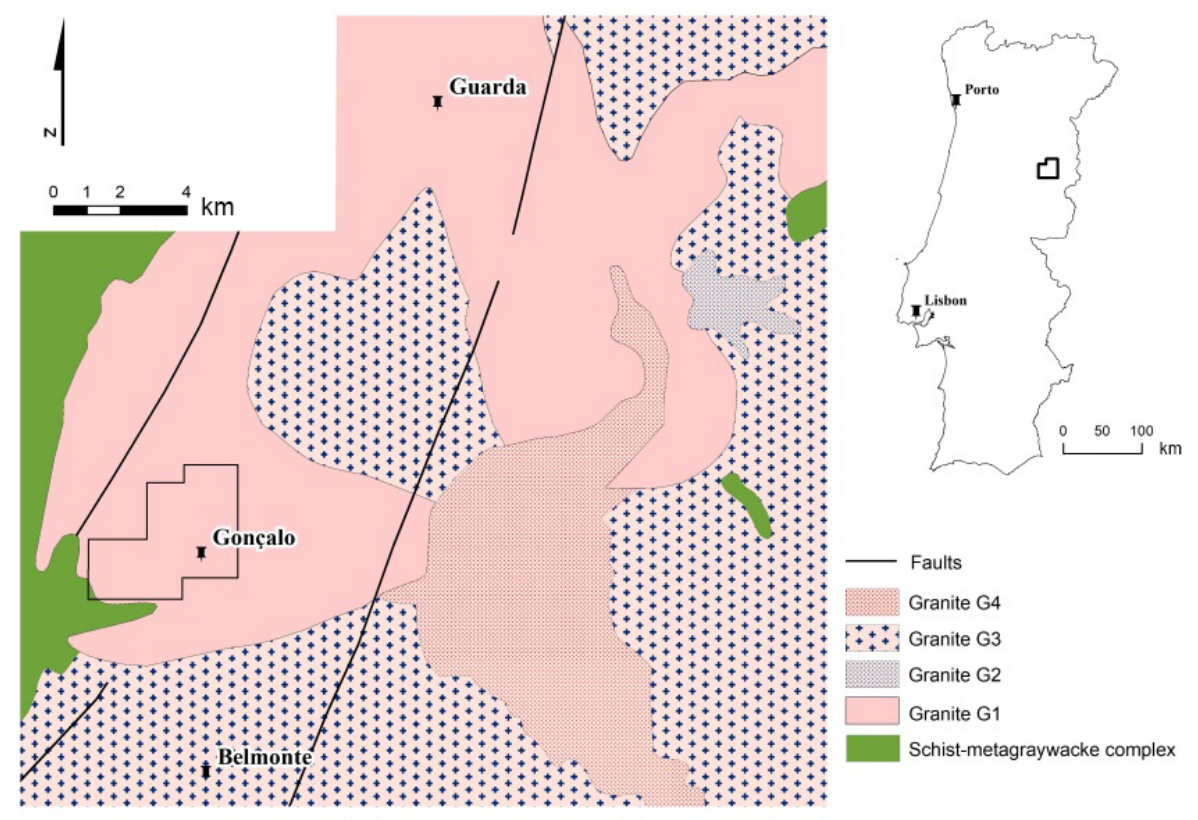

Figure 1. Geographic and geological setting of the lithium Alvarrões-Gonçalo deposit (adapted from Neiva and Ramos, 2010). G1 - biotite granite (Guarda granite); G2, G3 and G4 - biotite-muscovite granites.

ciated with the extraction and processing of minerals and metals, thus accomplishing the objective of "low production, high efficiency, low emissions". The ultimate goal of the "Green Mining" approach is the utilisation of all usable minerals and by-products and the maximum reduction of the amount of waste (e.g. Shi, 2012; Cuffari, 2017; GTK, 2018).

Mining industry can be considered as one of the greatest waste producers, being fundamental the construction of tailings dams for waste disposal. In consequence, it is also crucial to develop strategies to reduce the quantity of waste generated during all stages of the mining cycle (Miranda et al., 2005; Laurence, 2011).

On the scope of the H2020 Project FAME (Flexible And Mobile Economic Processing Technologies, Grant Agreement No. 641650), which aims at the improvement of processing technologies in order to recover critical materials and/or rare elements, such as W, Li and Sn, from European complex ore deposits, the Li-rich pegmatite deposit of Alvarrões-Gonçalo (Portugal) is being investigated (Broadbent et al., 2018). The deposit is located approximately $20 \mathrm{~km}$ south of Guarda city, Central Portugal. Currently, it is exploited by FELMICA for ceramics, aggregates and ornamental purposes.

The Li-rich pegmatites outcropping in the AlvarrõesGonçalo area are granitic and lepidolite-rich in composition and are hosted in a synorogenic Variscan $(304.1 \pm 3.9 \mathrm{Ma})$ (Neiva and Ramos, 2010) porphyritic biotite granite (Guarda granite) (Fig. 1). The majority of the known pegmatites occurs as violet-coloured sills, with a sub-horizontal plunge and ranging up to $3.5 \mathrm{~m}$ in thickness. The sills are heteroge- neous on what concerns their internal structure, textural aspects, minerals grain size and relative abundance/distribution and correspond to an association of pegmatite \pm aplite. The decrease of the grain size from the pegmatitic to the aplitic component is accompanied by a more massive structure and a more intense violet colour because the aplite is richer in fine lepidolite. The inferred mineral resource of the AlvarrõesGonçalo deposit was estimated in $1.5 \mathrm{Mt} @ 1.1 \% \mathrm{Li}_{2} \mathrm{O}$ (Lepidico, 2017).

According to the mineralogy of the Alvarrões-Gonçalo ore deposit, froth flotation seems to be the most adequate method to produce a lepidolite concentrate, which should be the primary product of this deposit (Amarante et al., 2004; Bulatovic, 2007). The concentrate would be furtherly converted into lithium compounds to supply, essentially, the industry of energy storage. Then, also by froth flotation, it would be possible to separate the quartz and feldspars, which are, along with mica, the main minerals present in the rejects of lepidolite flotation (Heyes et al., 2012). These two products can suitably supply the ceramic industry. In the framework of this research, a strategic mineral processing flowsheet was developed to enable an almost zero waste mineral processing of the Alvarrões-Gonçalo ore.

\section{Materials and methods}

\subsection{Mineralogy of the samples from Alvarrões-Gonçalo}

A representative sample of the pegmatite ore from the Alvarrões-Gonçalo deposit was investigated. In the Li sills 
Table 1. Major elements analysis of the lepidolite flotation reject.

\begin{tabular}{lccccccc}
\hline$\%$ Element & $\mathrm{Li}_{2} \mathrm{O}$ & $\mathrm{SiO}_{2}$ & $\mathrm{Al}_{2} \mathrm{O}_{3}$ & $\mathrm{Fe}_{2} \mathrm{O}_{3}$ & $\mathrm{Na}_{2} \mathrm{O}$ & $\mathrm{K}_{2} \mathrm{O}$ & LOI \\
\hline Lepidolite Flotation Reject & 0.61 & 74.63 & 14.76 & 0.19 & 4.65 & 1.96 & 1.12 \\
\hline
\end{tabular}

Table 2. Major elements analysis of the feldspars/quartz separation.

\begin{tabular}{lrrrrrrr}
\hline \% Element & $\mathrm{Li}_{2} \mathrm{O}$ & $\mathrm{SiO}_{2}$ & $\mathrm{Al}_{2} \mathrm{O}_{3}$ & $\mathrm{Fe}_{2} \mathrm{O}_{3}$ & $\mathrm{Na}_{2} \mathrm{O}$ & $\mathrm{K}_{2} \mathrm{O}$ & LOI \\
\hline High Content Feldspars Product & 0.95 & 65.60 & 20.01 & 0.25 & 5.82 & 2.63 & 1.65 \\
Quartz Product & 0.24 & 84.48 & 9.04 & 0.12 & 3.37 & 1.23 & 0.55 \\
\hline
\end{tabular}

outcropping in Alvarrões-Gonçalo, it is possible to distinguish a pegmatitic facies and an aplitic facies. The pegmatitic component is characterized by lepidolite $(>500 \mu \mathrm{m})$, albite, Li-muscovite, quartz and K-feldspar as major minerals, and montebrasite, topaz, cassiterite, columbo-tantalite, beryl and zircon as minor minerals. Although present, petalite is scarce due to its alteration to kaolinite, cookeite, pollucite and illite/smectite in late episodes of pegmatite history. Zinnwaldite also occurs but resulting from the metasomatic alteration of biotite on the contact of the host granite with the pegmatite sills. The aplitic component is very rich in lepidolite $(<250 \mu \mathrm{m})$, which is accompanied by other major minerals such as albite, montebrasite and quartz. Some muscovite, topaz, cassiterite and columbo-tantalite also occur (Charoy and Noronha, 1999; Ramos, 2007). In both components, secondary phosphates from late alteration processes are also present.

\subsection{Experimental testwork}

As mentioned above, the main objective of this work was to assess the possibility of applying the concept of "zero waste mining" to the exploitation of a pegmatite ore. For the purpose, a $3 \mathrm{t}$ ore sample from Alvarrões-Gonçalo (Portugal) deposit, averaging $1.20 \% \mathrm{Li}_{2} \mathrm{O}$, was on site primarily crushed to $<8 \mathrm{~mm}$.

Furtherly, the ore was processed by flotation to recover a high $\mathrm{Li}$ grade concentrate $\left(4.7 \% \mathrm{Li}_{2} \mathrm{O}\right)$ and, in a second step, the tails of the lepidolite flotation were also treated by flotation to produce a feldspars enriched product and a reject in which quartz is dominant. Lepidolite flotation was conducted under a $\mathrm{pH}$ of about $3.5\left(\mathrm{H}_{2} \mathrm{SO}_{4}\right)$ and using $200 \mathrm{~g} \mathrm{t}^{-1}$ of FLOTIGAM EDA as collector. Then, the $\mathrm{pH}$ was reduced to 2.5 with $\mathrm{HF}$ and $600 \mathrm{~g} \mathrm{t}^{-1}$ of AERO 3030C collector were added to enable the feldspar flotation. Chemical assaying, using an UNICAM-M series atomic absorption spectrometer (AAS) and a WDS X-ray fluorescence Philips PW 2404 spectrometer (XRF) were performed.

\section{Results and discussion}

\subsection{Results of the laboratory scale tests}

According to the flotation procedure, the first stage is the production of a lepidolite concentrate, which is the main commercial product. Concentrate grades between $4-5 \% \mathrm{Li}_{2} \mathrm{O}$ were achieved, which are adequate for the metallurgy of lithium compounds. The rejects of lepidolite flotation consist, mainly, in a mixture of quartz and feldspars (albite + $\mathrm{K}$-feldspar), as can be observed in Table 1 .

The second stage of the process consisted in the separation of feldspars and quartz by flotation, leading to the production of a feldspar enriched product (float) and a quartz product (flotation reject). Table 2 shows the major element assays performed by AAS for Li content and XRF for the other elements.

Based on the chemical assay of the major elements, it is possible to determine the content of the main minerals, assuming their stoichiometric composition. Thus, a computation model was developed to express the chemical composition of a mixture of those mains minerals, as a function of the chemical composition of each mineral, according to the Eq. (1):

$P_{x}=\sum_{i=1}^{n} E_{i} \times S_{x, i}$,

where $P_{x}$ is the chemical content of any oxide $\left(\mathrm{Li}_{2} \mathrm{O}, \mathrm{Si}_{2} \mathrm{O}\right.$, $\mathrm{Al}_{2} \mathrm{O}_{3}, \mathrm{Fe}_{2} \mathrm{O}_{3}, \mathrm{Na}_{2} \mathrm{O}, \mathrm{K}_{2} \mathrm{O}$ ) in the sample, $\mathrm{n}$ is the number of main minerals considered in the calculation, $E_{i}$ is the \% of the mineral in the sample $\left(E_{1}-\%\right.$ Lepidolite, $E_{2}-\%$ Quartz, $E_{3}-\%$ Albite, $E_{4}-\%$ K-Feldspar, $E_{5}-\%$ Muscovite, $E_{6}-\%$ Kaolinite), which is unknown and $S_{x, i}$ is the stoichiometric composition of the element in each mineral.

Thus, a numerical optimization algorithm, such as Excel SOLVER tool, was used to determine all the unknowns $\left(E_{i}\right)$ that minimize the deviation between the chemical assays and the calculated chemical composition, according to a criterion of the least squares. Table 3 shows the content of the main minerals in each product. As it is possible to observe, the "High Content Feldspars Product" shows a low quartz 
Table 3. Major elements analysis of the feldspars/quartz separation.

\begin{tabular}{lrrrrrr}
\hline$\%$ Mineral & Lepidolite & Quartz & Albite & K-Feldspar & Kaolinite & Muscovite \\
\hline High Content Feldspars Product & 12.00 & 13.90 & 52.30 & 6.00 & 8.09 & 5.45 \\
Quartz Product & 3.00 & 58.34 & 30.30 & 3.70 & 3.43 & 0.03 \\
\hline
\end{tabular}

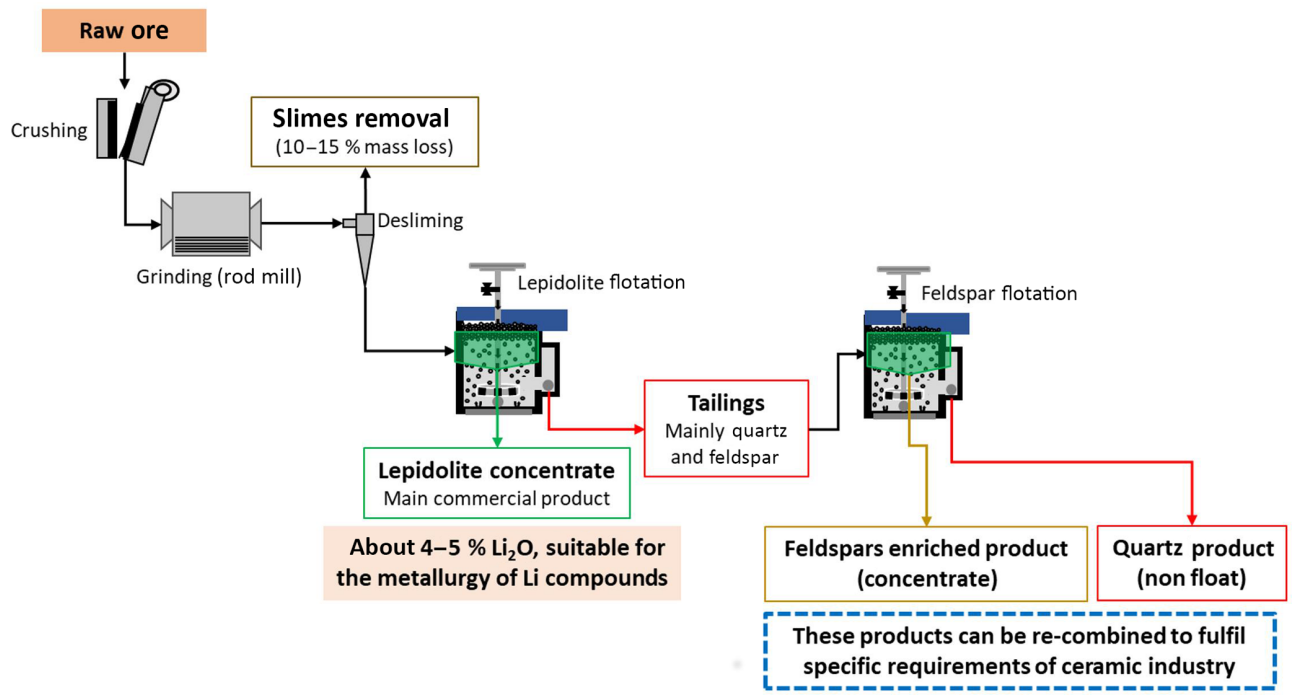

Figure 2. Flowsheet proposal for Alvarrões-Gonçalo ore deposit.

content and a high feldspars (albite + K-Feldspar) content, which indicate that it is possible to produce the desired products from the lepidolite flotation reject. It is also evident that feldspars activation must be enhanced to increase the content of feldspars in the floated fraction and, consequently, to obtain a quartz product with lower feldspars content.

\subsection{Flowsheet design for Alvarrões-Gonçalo - "zero waste" mining}

In the sequence of the main objective of this work, a flowsheet for the mineral processing of the Alvarrões-Gonçalo ore is proposed, based on lepidolite flotation batch results and on preliminary results of feldspars/quartz separation. The flowsheet, shown in Fig. 2, was conceived according to the "zero waste" concept, and is now being tested in continuous flow in a Mineral Processing Plant at LNEG premises, in Portugal.

Thus, the processing flowsheet starts with a comminution stage (grinding in a rod mill) to obtain the most suitable size particle for lepidolite liberation $\left(k_{80}=0.160 \mathrm{~mm}\right)$. Then, a crucial desliming step on a hydro-cyclone must be performed to remove very fine particles (cut size $\approx 0.060 \mathrm{~mm}$ ), which reduces the flotation efficiency and increases the reagent consumption. After that, a high Li grade concentrate $(4.7 \%$ $\mathrm{Li}_{2} \mathrm{O}$ ) is obtained by flotation in a 6 cells bank (35 L each); the tails of the lepidolite recovery are then floated again to obtain a feldspar enriched product.
The lepidolite concentrate is suitable for Li metallurgy. The other 3 products, "Feldspars/Mica" enriched product, "Quartz based" product and "Slimes" have applications in several segments of ceramics: the feldspar concentrate could be mixed with the original material to produce tailored final products, with some Li content, to satisfy customer needs; the rejected quartz is not suitable for silica flour, but can be used in blendings; further studies are under research to optimize the removal of mica minerals prior to feldspar flotation, and to find an application for the "Slimes" product.

\section{Conclusions}

The Alvarrões-Gonçalo deposit can be considered a notable example of a sustainable mining, reaching the goal of an almost "zero waste" exploitation. It has been demonstrated that Mineral Processing is able to contribute to the enlargement of the added-value chain: a high $\mathrm{Li}_{2} \mathrm{O}$ lepidolite concentrate is suitable for use in the industry of lithium compounds and several by-products that can fit specific needs of raw materials for ceramic bodies. However, some challenges must be accomplished to improve the proposed flowsheet: the possibility of obtaining concentrate grades closer the stoichiometry of lepidolite (increasing liberation in finer sizes); removal of mica minerals prior to feldspars flotation to reach a higher quality feldspar; and looking for an application of slimes, avoiding their release in a dump. 
Data availability. All data were obtained under the scope of the European H2020 Project - FAME. At the moment, all reports are confidential, as required by the Consortium Agreement.

Author contributions. RS, ABdS and MML were responsible for all the experimental test work and results. VR, AG, FN, RS and AD were responsible for the mineralogical studies.

Competing interests. The authors declare that they have no conflict of interest.

Special issue statement. This article is part of the special issue "European Geosciences Union General Assembly 2018, EGU Division Energy, Resources \& Environment (ERE)"'. It is a result of the EGU General Assembly 2018, Vienna, Austria, 8-13 April 2018.

Acknowledgements. This project is funded by the EU Horizon 2020 Project "FAME": Flexible and Mobile Processing Technologies (grant \#641650). The authors acknowledge the contributions of the FAME team for sample collection and preparation and scientific discussions that led to the development of this paper. Rui Sousa acknowledges the "Fundação para a Ciência e Tecnologia" for the scholarship programme with the reference SFRH/BD/114764/2016. Violeta Ramos, Fernando Noronha and Alexandra Guedes acknowledge the funding by COMPETE 2020 through the ICT project (UID/GEO/04683/2013) with POCI-010145 reference - FEDER-007690. The authors acknowledge the Topical Editor Luke Griffiths and two Anonymous Reviewers for their valuable comments.

Edited by: Luke Griffiths

Reviewed by: two anonymous referees

\section{References}

Amarante, M. M., Sousa, A. M. B., Oliveira, A., Ramos, J. M. F., Grade, J. C., and Leite, M.: Processamento de Minérios de Lítio - Contribuição para a Valorização Tecnológica de Espodumenas e Petalites. Relatório de projecto FCT, Secção de Processamento de Matérias Primas, IGM, Internal report, 27 pp., 2004.

Arndt, N. T., Fontboté, L., Hedenquist, J. W., Kesler, S. E., Thompson, J. F. H., and Wood, D. G.: Future global mineral resources, Geochem. Perspect., 6, 1-171, https://doi.org/10.7185/geochempersp.6.1, 2017.

Broadbent, C. P., Machado Leite, M., Andersen, J. C., and Martin, M.: FAME: Helping to valorize European lithium resources, Abstracts Book of the Lithium Conference, From Exploration to End-User, The Geological Society of London, Burlington House, 10-11 April 2018.

Bulatovic, S. M.: Handbook of Flotation Reagents: Chemistry, theory and practice - Flotation of Industrial Minerals, 1st Edn., Elsevier Science, ISBN 978-0-444-53082-0, 2007.
Burlakovs, J., Jani, Y., Kriipsalu, M., Vincevica-Gaile, Z., Kaczala, F., Celma, G., Ozola, R., Rozina, L., Rudovica, V., Hogland, M., Viksna, A., Pehme, K., Hogland, W., and Klavins, M.: On the way to "zero waste" management: Recovery potential of elements, including rare earth elements, from fine fraction of waste, J. Clean. Prod., 186, 81-90, https://doi.org/10.1016/j.jclepro.2018.03.102, 2018.

Charoy, B. and Noronha, F.: Rare-Element (Li-rich) granitic and pegmatitic plutons: A primary or superimposed signature?, Revista Brasileira de Geocências, 29, 3-8, available at: http:// ppegeo.igc.usp.br/index.php/rbg/article/view/11123 (last access: 3 May 2018), 1999.

Cuffari, B.: Making Green Mining a Reality, AZO Mining, https: //www.azomining.com/Article.aspx?ArticleID=1370 (retrieved on: 7 May 2018), 2017.

GTK: http://en.gtk.fi/mineral_resources/greenmining.html, retrieved on: 7 May 2018.

Heyes, G. W., Allan, G. C., Bruckard, W., and Sparrow, G. J.: Review of flotation of feldspar. Mineral Processing and Extractive Metallurgy IMM Transactions, Section C, 121, 72-78, https://doi.org/10.1179/1743285512Y.0000000004, 2012.

Laurence, D.: Establishing a sustainable mining operation: an overview, J. Clean. Prod., 19, 278-284, https://doi.org/10.1016/j.jclepro.2010.08.019, 2011.

Lepidico: Inaugural Alvarrões Mineral Resource Estimate, ASX/Media Announcement, 28 pp., 7 December 2017.

Miranda, M., Chambers, D., and Coumans, C.: Framework for responsible mining: a guide to evolving standards, http://www. frameworkforresponsiblemining.org (retrieved on: 2 May 2018), 2005.

Neiva, A. M. R. and Ramos, J. M. F.: Geochemistry of granitic aplite-pegmatite sills and petrogenetic links with granites, Guarda-Belmonte area, central Portugal, Eur. J. Mineral., 22, 837-854, https://doi.org/10.1127/0935-1221/2010/0022-2072, 2010.

Ramos, J. M. F.: Locality no 5: Seixo Amarelo-Gonçalo rare element aplite-pegmatite field, In Granitic pegmatites: The state of the art - field trip guidebook, Memórias No. 9, edited by: Lima, A. and Roda Robles, E., Departamento de Geologia da Faculdade de Ciências, Universidade do Porto, Porto, Portugal, 72-86, ISSN 0871-1607, 2007.

Sauer, P. and Seuring, S.: Sustainable supply chain management for minerals, J. Clean. Prod., 151, 235-249, https://doi.org/10.1016/j.jclepro.2017.03.049, 2017.

Shi, H.-Q.: Mine green mining, Energy Proced., 16, 409-416, https://doi.org/10.1016/j.egypro.2012.01.067, 2012.

Sverdrup, K. and Ragnarsdottir, V. K.: Natural resources in a planetary perspective, Geochem. Perspect., 3, 129-341, https://doi.org/10.7185/geochempersp.3.2, 2014.

United Nations: Report of the World Commission on Environment and Development: Our Common Future, http://www. un-documents.net/wced-ocf.htm (retrieved on: 2 May 2018), 1987.

ZWIA: Zero Waste International Alliance (ZWIA), Zero Waste Definition, http://zwia.org/standards/zw-definition (retrieved on: 2 May 2018), 2015. 